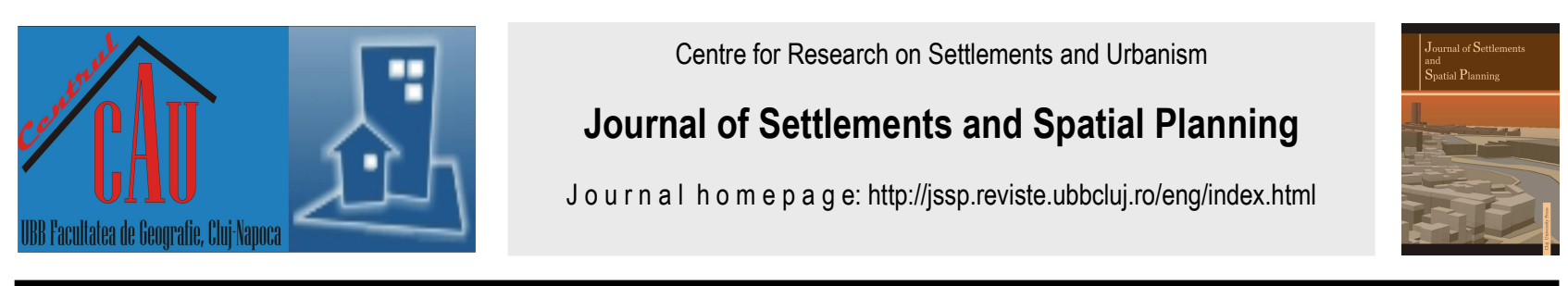

\title{
Business Urban Sprawl. A Financial Evaluation of Enterprises in Poland
}

\author{
Piotr LITYŃSKI ${ }^{* 1}$ \\ * Corresponding author \\ 1 Cracow University of Economics, Institute of Spatial Development and Urban Studies, College of Public Economy and \\ Administration, Department of Spatial Development, Cracow, POLAND \\ $\triangle$ litynskp@uek.krakow.pl (iD https://orcid.org/oooo-ooo2-1400-5545 \\ DOI: 10.24193/JSSPSI.O2.CSPTER \\ https://doi.org/10.24193/JSSPSI.02.CSPTER
}

K e y w o r d s: urban sprawl, enterprises, costs and benefits, ratio analysis, spatial policy, business decentralization

\begin{abstract}
A B S T RA C T
The aim of the article is to assess the costs and benefits of enterprises situated in urban sprawl areas in Poland. The main hypothesis is that urban sprawl is beneficial for the businesses located within the urban sprawl area. The synthetic control method used is based on the results of surveys and financial data provided by the Central Statistical Office in Poland for the enterprises located within the urban sprawl area. The object of the research is therefore the finances of those enterprises that are based around the largest Polish cities. The main hypothesis was positively verified. The results of the investigation indicate that lower wage costs are not more significant compared to those of the economic entities in the control group. The benefits for enterprises located in the urban sprawl zone were also diagnosed, including lower burdens resulted from real-estate taxes, energy, foreign services. The added value of the research is also the indication of the financial mechanism of benefits from the location of business entities in the urban sprawl zone. This mechanism is based on the reduction of spatial costs, more efficient use of fixed assets and more intensive use of production factors.
\end{abstract}

\section{INTRODUCTION}

In economic sciences, a number of models and theories explaining the processes determining spatial changes in urban areas have been developed, starting with Ricardo's concept of land rent and von Thünen's concept of agricultural income. In the literature featuring the economic side of urban sprawl, attention is drawn to the division of the concept into two classes (Bayoh et al., 2002; Mieszkowski and Mills, 1993). The first is the theory of the natural evolution of urban areas, which includes monocentric city models and models of decentralization of urban functions. The second category is represented by the fiscal and social theories distinguishing external effects, bearing at the same time the original names such as: "flight from blight" or, "voting with your feet".
The theories of the natural evolution of the city are essential to reflect the consequences of urban sprawl for enterprises and understand their role in shaping this spatial phenomenon. Part of this class of theoretical concepts, the model of the monocentric city, referred to as the Alonso-Muth-Mills (AMM) model, was developed by three economists: Alonso (1964), Mills (1967) and Muth (1969). The concept of the natural evolution of the city is also reflected by other models of decentralization of urban functions, such as the Lave model of economics of decentralization (1974) and the Fujita-Ogawa (F-O) model. The F-O model (1982) is considered to be one of the first to explain the role of transport costs in shaping the decentralized spatial structure of an urban area, and today it finds further developments, e.g. in the ABM model (agentbased model) by Heikkila and Wang (2009). 
The AMM model explains the shaping of suburbanization. In this model, when the city grows, commercial buildings are located in other districts, and residential areas are pushed outside the city limits - into suburbia. The increase in new housing development in the periphery, usually consisting of single-family houses, results in the migration of wealthier social strata to these areas. Old urban districts are left to the social groups with lower incomes (Mieszkowski and Mills, 1993). The described process is a natural mechanism which, at the same time, leads to the financial stratification of society in the urban area. As a consequence, social groups with a lower income remain in the city, whilst wealthier households settle in the suburbs. Suburbanization is intensified by the preferences of the middle class, which values residential buildings more than multi-family buildings, and ultimately decides to choose the suburbs as a living area. In the theory of the natural evolution of the city, it is noted that the tendency of the middle class to inhabit suburbs has been reinforced by the development of transport (Brueckner, 1987; Mills, 2000; Nechyba and Walsch, 2004; Spivey, 2008). The movement of the population into the suburbs will entail decentralization of employment - that is, the relocation of economic activities from the city centre to the suburbs. The relocation of economic activities results from the creation of new markets for goods and services for the local communities in the suburbs. At the same time, there are lower real-estate and salary costs in the suburbs, which further stimulate economic entities to relocate in these areas (Bayoh et al., 2002; Wu, 2007; Hołuj, 2018).

Lave (1974) develops the theory by proposing the so-called economics of decentralization, which shows that growing urban areas are becoming more and more decentralized. This decentralization aims to reduce the share of jobs in one city centre. Outside the central city, in the neighbouring municipalities, there are employers who, on a large scale, may influence the spatial structure of the entire urban area. Thus, the reality, confirmed empirically, is the multiplicity of employment centres in urban areas, called polycentricity or multicentricity (Fujita and Ogawa, 1982; White, 1976, 1988; Sullivan, 1986; Wieand 1987; Wheaton, 2004). These decentralization models indicate two main cost benefits related to the suburban location of enterprises (Li et al., 2019): lower wages and real-estate costs.

The F-O model refers to the location decisions of economic entities in an urban area (Fujita and Thisse, 2002). The essence of the concept is the identification of the degree of dependence between agglomeration effects and transport costs. The model shows that economic entities tend to cluster, and the high costs of commuting to work affect the change of residential location close to the workplace. Motivations captured in this way result in competition between economic entities and households for the occupation of the most advantageous land. In the F-O model it is possible to alternate between residential and economic zones. The relatively high commuting costs lead to the formation of several centres of economic activity and residential subdivisions, creating a polycentric structure of the urban area.

An extension of the F-O model is the ABM model (agent-based model) proposed by Heikkila and Wang (2009), which includes three basic components: the so-called agents (households and businesses), the environment and the rules of conduct. Agents are characterized by individual attitudes; some are static and others may be modified, such as preferences or rules of behaviour. The environment is defined as a two-dimensional space that consists of resources and a communication network. The rules of conduct define the interactions between agents and the environment, and within the environment. This model shows that the introduction of several centres to the monocentric model has a positive impact, i.e. an increase in agents' income, lowering transport expenses, weakening competition for space between households and economic entities. The distances covered are also reduced, which provides positive environmental effects. White (1988) explains the employment decentralization model and its impact on the shaping of suburbanization processes. The model allows for the analysis of wage and competency differentiation in individual suburban locations. It also becomes possible to analyze the change of location of business entities into the suburban areas. The employment decentralization model significantly develops the AMM theories, indicating that longer commuting distances are not in all circumstances compensated by lower real-estate prices and higher earnings. Moreover, they explain that salaries and real-estate prices adjust to further distances depending on the direction of travel.

The models of the natural evolution of the city interpenetrate, which sometimes makes it difficult to clearly distinguish between them. To sum up, in these models, the dispersion of jobs from the city centre to suburbia plays a fundamental role in the models of decentralization of urban functions. In part, this decentralization is related to the diversification of the location of households, followed by economic agents. Decentralization also results from the decision to relocate economic entities based on an economic account, pointing to suburbia as more favourable. It should be noted that the absence of this centrifugal movement would limit the growth of the urban area, especially during periods of population growth in the city. Decentralization is therefore a natural process of spatial growth in an urban area, because households, striving to maximize their utility, rationalize the costs of commuting to work through employment in the 


\section{Business Urban Sprawl. A Financial Evaluation of Enterprises in Poland Journal of Settlements and Spatial Planning, Special Issue, (2022) 5-13 Cities, Suburbs and Peripheries in Theory and Empirical Research}

suburbs. Enterprises, on the other hand, benefit from lower wages and real-estate costs.

The natural evolution theory is a concept around which the link between urban sprawl and economic entities is being discussed currently. It should also be added that these theories and models describe rather simple suburbanization processes, and there are no models in the economic literature attempting to explain suburbanization characterized by the spontaneity of the building space. Thus, a research gap arises, which concerns the lack of knowledge on the financial consequences registered by the enterprises located in urban sprawl zone. Thus, the aim of the article is to assess the costs and benefits of enterprises located in urban sprawl areas in Poland. The main hypothesis is that urban sprawl is beneficial for businesses. The set goal and research hypothesis were verified based on questionnaire research and a database of balance sheets and profit and loss accounts of enterprises. The data were provided by the Central Statistical Office in Poland. Methodologically, the synthetic control method was used to achieve the research goal. The proposed research is therefore innovative. The novelty lies in the fact that the companies located in urban sprawl zones were included in the research. Moreover, the research conducted so far was designed as a general assessment of wages and transport costs. There is no in-depth evaluation of the financial condition and mechanisms of such enterprises, which would use data from balance sheets and profit and loss accounts of enterprises. Therefore, the novelty of the presented research also has a methodological dimension, as the analyses use detailed financial data from balance sheets and profit and loss accounts.

\section{THEORY AND METHODOLOGY}

The aim of the study is to assess the costs and benefits for enterprises located in urban sprawl areas in Poland. Therefore, the subjects of the research are enterprises located in municipalities affected by urban sprawl in Poland. The financial consequences are the main subject of the research, while the area of under study consists of the communes with the risk of being affected by urban sprawl in Poland, as indicated by Lityński and Hołuj (2020). The research area covers communes around the largest Polish cities that are capitals of regions, as indicated in Figure 1.

The current state of knowledge concerning the models of decentralization of urban functions shows that the dispersion of jobs from the city centre to the suburbia results from the increased profitability of economic activities (Alonso, 1964; Fujita and Ogawa, 1982; Heikkila and Wang, 2009). There are two main cost benefits associated with the suburban location of enterprises (Li at al., 2019): lower wages and real-estate costs. The methodological identification of costs or benefits must therefore take into account both the specific financial categories (e.g. salary costs categories), but also the appropriate cost or benefits assessment method.

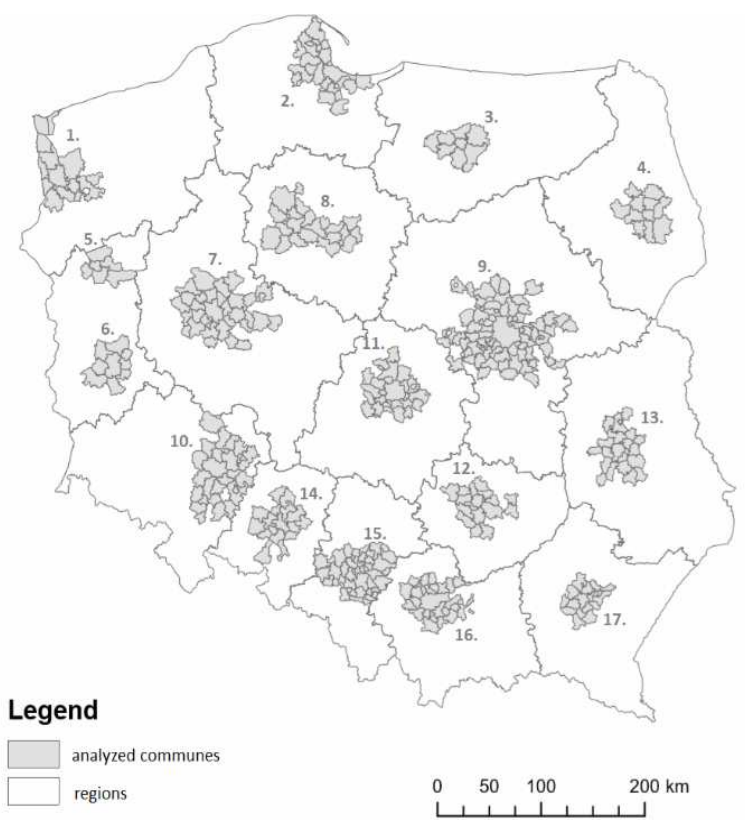

Fig. 1. Analyzed urban areas: 1. Szczecin. 2. Gdańsk. 3. Olsztyn. 4. Białystok. 5. Gorzów. 6. Zielona Góra. 7. Poznań. 8. Toruń. 9. Warszawa (Poland Capital). 10. Wrocław. 11. Łódź. 12. Kielce. 13. Lublin. 14. Opole. 15. Katowice. 16. Kraków. 17. Rzeszów (source: own study based on Lityński and Hohuj, 2020).

The synthetic control method was used to identify the enterprises' operating costs and benefits. The essence of such research is to compare their financial situation with that of enterprises from the control group. The research assumed that the control group would be represented by the enterprises located in central cities. The comparison of both sets was made using the $d$ Cohena indicator (Livingston et al., 2009):

$$
\mathrm{d} \text { Cohena }=\frac{\overline{x_{a g}}-\overline{x_{c g}}}{s}
$$

where:

$$
\begin{aligned}
& \overline{x_{a g}}-\text { average for the analyzed group; } \\
& \overline{x_{c g}}-\text { average for the control group; } \\
& S-\text { standard deviation in the population. }
\end{aligned}
$$

In this method, the net effect is assessed in the following value ranges: 0 means no effect; $0-0.2$ small; 0.2-0.5 moderate; 0.5-0.8 large and statistically significant; > 0.8 very high. When $d$ Cohena results in values with "+" then the effect is assessed positively as net benefit, and when it has values with "_." it is assessed negatively as net cost. The $d$ Cohen's assessment was carried out in relation to the financial indicators 
Table 1. Set of indicators assessing the financial condition of enterprises.

\begin{tabular}{|c|c|c|}
\hline Name of the indicator & Formula & Interpretation \\
\hline \multicolumn{3}{|r|}{ Cost analysis } \\
\hline Wageburden & $B_{(w)}=\frac{C_{w a}}{C_{o p}}$ & \\
\hline Property taxes burden & $B_{(p t)}=\frac{C_{t x}-C_{e x}}{C_{o p}}$ & \multirow{2}{*}{$\begin{array}{l}\text { Indicates the importance of a specific cost in the functioning of the } \\
\text { enterprise }\end{array}$} \\
\hline External services burden & $B_{(e s)}=\frac{C_{e s}}{C_{o p}}$ & \\
\hline Energy burden & $B_{(e n)}=\frac{C_{e n}}{C_{o p}}$ & \\
\hline \multicolumn{3}{|c|}{ Sales revenue analysis } \\
\hline Costlevelindicator & $S_{(r v)}=\frac{C_{s i}}{R_{s i}}$ & $\begin{array}{l}\text { Indicates the profitability of the enterprise's operation when costs are lower } \\
\text { than revenues }\end{array}$ \\
\hline \multicolumn{3}{|c|}{ Asset resource analysis } \\
\hline Assetproductivity index & $A_{(p i)}=\frac{A_{t g}}{A_{f i}}$ & $\begin{array}{l}\text { Entities with a predominance of tangible assets are in a better position; } \\
\text { tangible property creates financial wealth; without production / commercial } \\
\text { activities, it is difficult for entities to obtain funds }\end{array}$ \\
\hline Assetutilizationrate & $A_{(u r)}=\frac{R_{s i}}{A_{t t}}$ & Indicates the company's property's ability to generate sales revenue \\
\hline Fixedassetsstructureindicator & $A_{(s c)}=\frac{A_{p f x}}{A_{f x}}$ & $\begin{array}{l}\text { Productivity measure; if the structure of fixed assets is dominated by } \\
\text { passive elements (land, buildings, structures) then it proves low } \\
\text { productivity }\end{array}$ \\
\hline Asset return ratio & $A_{(r r)}=\frac{P_{n e t}}{A_{t t}}$ & $\begin{array}{l}\text { Is a measure of the effectiveness of the use of assets; there are differences } \\
\text { between the utilization and profitability ratios: the first reflects the } \\
\text { processes of increasing the use of assets and increasing sales revenues, the } \\
\text { second takes into account: cost reduction, more efficient fixed assets, more } \\
\text { intensive use of production factors }\end{array}$ \\
\hline \multicolumn{3}{|l|}{ Where: } \\
\hline$C_{o p}$ - Operating costs & \multirow{6}{*}{\multicolumn{2}{|c|}{$\begin{array}{l}C_{s l}-\text { Sales own costs } \\
A_{t g}-\text { Tangible assets } \\
A_{f i}-\text { Financial assets } \\
A_{t t}-\text { Total assets } \\
R_{s l}-\text { Sales revenues } \\
A_{f x}-\text { Total fixed assets }\end{array}$}} \\
\hline$C_{e n}$ - Energy costs & & \\
\hline$C_{e s}$ - External services costs & & \\
\hline$C_{t x}-$ Taxes & & \\
\hline$C_{e x}$-Excise & & \\
\hline$C_{w a}-$ Wages & & \\
\hline
\end{tabular}

The data necessary for the calculation of the indicators was purchased from the Central Statistical Office (CSO). These are data from balance sheets and profit and loss accounts for 2016. The limitation of the CSO databases, however, is the impossibility to indicate a specific location of the enterprises, as data on these entities are aggregated to the commune level. This database provides information about the finances of companies in the municipality. However, from this database we do not know whether the companies are located in the part of the municipality that is characterized by compact development, and therefore is not affected by urban sprawl; or, if they are located away from the urbanized part of the commune, and, therefore, in the sprawl zone. Thus, the research proposed to cushion this limitation by checking the convergence of the GUS databases with the sample of enterprises operating in the sprawl zone. The analysis of convergence became the first of the tasks undertaken in the study, while the selection of indicators indicated in Table 1 and d Cohen's were performed only for those financial items that converged.

The analysis of convergence is primarily related to the identification of a sample of enterprises based on a survey. The survey was conducted in the area of Cracow, Poland. The selection of the sample in the surveys was random. Using the REGON address database for 2018, purchased from the CSO, it was possible to determine the geographic location of the enterprises, including the selected 50 enterprises, while maintaining the industry structure appropriate for the surveyed area. The survey was conducted in August- 


\section{Business Urban Sprawl. A Financial Evaluation of Enterprises in Poland Journal of Settlements and Spatial Planning, Special Issue, (2022) 5-13 \\ Cities, Suburbs and Peripheries in Theory and Empirical Research}

September 2018, by 4 people with professional experience at the CSO in the field of collecting financial data. The structure of the survey corresponded to the items known from the balance sheet and profit and loss account. This structure of the survey is presented in Table 2. surveys.

Table 2. Financial variables in questionnaire

\begin{tabular}{|c|c|}
\hline Symbol & Financial statement items \\
\hline \multicolumn{2}{|r|}{ Balance Sheet } \\
\hline A. & Assets \\
\hline A.I. & Intangibleassets \\
\hline A.II. & Tangiblefixedassets \\
\hline A.II.a. & Value of fixed assets owned \\
\hline A.II.a.1 & Land \\
\hline A.II.a.2. & Buildings \\
\hline A.II.a.3. & Technical devices and machines \\
\hline A.II.a.4. & Means of transport \\
\hline A.II.a.5. & Other fixed assets \\
\hline A.II.b. & Fixed assets under construction \\
\hline A.III. & Long-term receivables \\
\hline A.IV. & Long-term investments \\
\hline A.V. & Long-term prepayments \\
\hline A.VI. & Inventories \\
\hline A.VII. & Short-term receivables \\
\hline A.VIII. & Short-term investments \\
\hline A.IX. & Short-term prepayments \\
\hline B. & Liabilities \\
\hline B.I. & Equity \\
\hline B.II. & Long-term obligations \\
\hline B.III. & Current liabilities \\
\hline B.IV. & Accruals \\
\hline \multicolumn{2}{|r|}{ Profit and Loss Statement } \\
\hline C.I. & Net sales revenue \\
\hline C.II. & Amortization \\
\hline C.III. & Materials and energy \\
\hline C.III.a. & Energy \\
\hline C.IV. & External services \\
\hline C.V. & Taxes and charges as part of operating expenses \\
\hline C.VI. & Wages \\
\hline C.VII. & Social security and other benefits \\
\hline C.VIII. & Other costs \\
\hline C.IX. & Costs of products for own needs \\
\hline C.X. & Other operating income \\
\hline C.XI. & Other operating expenses \\
\hline C.XII. & Income tax \\
\hline
\end{tabular}

The second step of the convergence analysis was to compare the financial situation of the surveyed enterprises with that of enterprises recorded in the statistical database. The $U_{i}$ test was used for this comparison:

$$
U_{i}=\frac{\left|\overline{x_{1}}-\overline{x_{2}}\right|}{\sqrt{\left(\frac{s_{1}^{2}}{n_{1}}-\frac{s_{2}^{2}}{n_{2}}\right)}}
$$

where:

$$
\begin{aligned}
& \overline{x_{1}}, \overline{x_{2}}-\text { averages; } \\
& \mathrm{s}_{1}, \mathrm{~s}_{2}-\text { standard deviations; } \\
& \mathrm{n}_{1}, \mathrm{n}_{2}-\text { group size. }
\end{aligned}
$$

The tested statistical hypotheses are $\mathrm{H}_{\mathrm{o}}$ : $\overline{x_{1}}=\overline{x_{2}}$, and $\mathrm{H}_{1}: \bar{x}_{1} \neq \bar{x}_{2}$. In the $\mathrm{U}_{\mathrm{i}}$ test, the critical area is determined by $\mathrm{U}_{a}$, which is read from the Student t-distribution table. In the research, $\alpha=0.05$ was assumed. If there is an inequality of $U_{i} \geq U_{a}$, then we reject $\mathrm{H}_{\mathrm{o}}$ in favour of $\mathrm{H}_{1}$, which means that it is impossible to make inferences about the financial situation of enterprises operating in the conditions of urban sprawl based on the information provided by the CSO databases. If there is an inequality $\mathrm{U}_{\mathrm{i}}<\mathrm{U}_{a}$, then there is no reason to reject $\mathrm{H}_{\mathrm{o}}$, which means that we can infer based on the information provided by the CSO databases.

\section{RESULTS AND DISCUSSION}

Table 3 presents the average values of the financial items of the balance sheet and the profit and loss account for the enterprises under analysis, based on the data provided by the CSO databases and collected from the conducted surveys.

In Table 3, we also reveal the values of the $\mathrm{U}_{\mathrm{i}}$ test, where the items marked in gray represent $H_{1}$, which for these items prevents making inferences based on information from the CSO databases. Thus, items C.II.; C.XI. and C.XII. cannot be considered when

\begin{tabular}{|c|c|c|c|c|c|}
\hline \multirow[t]{2}{*}{ Variable } & \multicolumn{2}{|c|}{$\operatorname{CSO}[N=264]$} & \multicolumn{2}{|c|}{$\begin{array}{c}\text { Questionnaire } \\
{[\mathrm{N}=50]}\end{array}$} & \multirow[t]{2}{*}{$\mathrm{U}_{\mathrm{i}}$} \\
\hline & $x_{i}$ & $s_{i}$ & $x_{i}$ & $s_{i}$ & \\
\hline A. Assets & 23706 & 3303 & 24854 & 3922 & 1.94 \\
\hline A.I. Intangible assets & 138 & 25 & 145 & 29 & 1.51 \\
\hline A.II. Tangible fixed assets & 9428 & 1442 & 9885 & 1712 & 1.77 \\
\hline A.II.a. Value of fixed assets owned & 9079 & 1406 & 9518 & 1670 & 1.75 \\
\hline A.II.a.1. Land & 760 & 135 & 796 & 161 & 1.52 \\
\hline A.II.a.2. Buildings & 5787 & 1015 & 6067 & 1205 & 1.54 \\
\hline A.II.a.3. Technical devices and machines & 1769 & 328 & 1854 & 389 & 1.46 \\
\hline
\end{tabular}
constructing the financial indicators.

Table 3. Average values of balance sheet items and profit and loss statement items in the CSO databases and questionnaire surveys in thous. PLN (source: own study based on CSO data and questionnaire surveys). 


\begin{tabular}{|c|c|c|c|c|c|}
\hline A.II.a.4. Means of transport & 515 & 97 & 540 & 116 & 1.43 \\
\hline A.II.a.5. Other fixed assets & 249 & 45 & 261 & 53 & 1.50 \\
\hline A.II.b. Fixed assets under construction & 270 & 37 & 283 & 44 & 1.95 \\
\hline A.III. Long-term receivables & 93 & 23 & 97 & 27 & 1.09 \\
\hline A.IV. Long-term investments & 1001 & 233 & 1050 & 276 & 1.16 \\
\hline A.V. Long-term prepayments & 416 & 98 & 436 & 116 & 1.15 \\
\hline A.VI. Inventories & 3898 & 660 & 4086 & 784 & 1.60 \\
\hline A.VII. Short-term receivables & 5692 & 877 & 5967 & 1042 & 1.76 \\
\hline A.VIII. Short-term investments & 2824 & 458 & 2961 & 544 & 1.67 \\
\hline A.IX. Short-term prepayments & 215 & 39 & 225 & 46 & 1.51 \\
\hline B. Liabilities & 23706 & 3303 & 24854 & 3922 & 1.94 \\
\hline B.I. Equity & 11948 & 1710 & 12526 & 2031 & 1.89 \\
\hline B.II. Long-term obligations & 1020 & 176 & 1070 & 208 & 1.57 \\
\hline B.III. Current liabilities & 8494 & 1365 & 8906 & 1621 & 1.68 \\
\hline B.IV. Accruals & 1780 & 420 & 1866 & 499 & 1.15 \\
\hline C.I. Net sales revenue & 36760 & 4753 & 37851 & 5112 & 1.40 \\
\hline C.II. Amortization & 858 & 112 & 899 & 117 & 2.31 \\
\hline C.III. Materials and energy & 5745 & 824 & 5982 & 850 & 1.81 \\
\hline C.III.a. Energy & 191 & 25 & 198 & 26 & 1.83 \\
\hline C.IV. External services & 4627 & 667 & 4800 & 699 & 1.62 \\
\hline C.V. Taxes and charges as part of operating expenses & 216 & 37 & 226 & 39 & 1.75 \\
\hline C.VI. Wages & 4852 & 846 & 5087 & 887 & 1.73 \\
\hline C.VII. Social security and other benefits & 1121 & 206 & 1176 & 216 & 1.64 \\
\hline C.VIII. Other costs & 1110 & 200 & 1164 & 209 & 1.68 \\
\hline C.IX. Costs of products for own needs & 114 & 27 & 119 & 29 & 1.25 \\
\hline C.X. Other operating income & 704 & 122 & 738 & 128 & 1.74 \\
\hline C.XI. Other operating expenses & 480 & 84 & 550 & 110 & 4.26 \\
\hline C.XII. Income tax & 143 & 42 & 165 & 44 & 3.21 \\
\hline
\end{tabular}

Table 4 reveals the average values of financial ratios calculated based on only those financial variables for which $\mathrm{H}_{0}$ is met. Companies located in a rural commune $\left(\mathrm{AG}_{2}\right)$ which are particularly exposed to urban sprawl were additionally identified. data).

Table 4. Value of financial indicators for enterprises from the analyzed and control groups (source: own study based on CSO

\begin{tabular}{l|cccccccccc}
\multicolumn{1}{c|}{ Grup } & $\mathrm{B}_{(\mathrm{w})}$ & $\mathrm{B}(\mathrm{pt})$ & $\mathrm{B}_{(\mathrm{es})}$ & $\mathrm{B}_{(\mathrm{en})}$ & $\mathrm{S}_{(\mathrm{rv})}$ & $\mathrm{A}_{(\mathrm{pi})}$ & $\mathrm{A}_{(\mathrm{ur})}$ & $\mathrm{A}_{(\mathrm{sc})}$ & $\mathrm{A}_{(\mathrm{rr})}$ \\
\hline $\mathrm{CG}$ & 0.114 & 0.017 & 0.169 & 0.021 & 0.960 & 4.016 & 1.146 & 0.672 & 0.044 \\
$\mathrm{AG}_{1}$ & 0.108 & 0.010 & 0.146 & 0.012 & 0.943 & 6.340 & 1.605 & 0.660 & 0.084 \\
$\mathrm{AG}_{2}$ & 0.104 & 0.009 & 0.141 & 0.010 & 0.943 & 6.823 & 1.705 & 0.649 & 0.089
\end{tabular}

Where:

$\mathrm{AG}_{1}$ - analyzed group 1: all communes outside the core city;

$\mathrm{AG}_{2}$ - analyzed group 2: rural communes outside the core city.

Table 5 presents the results of the calculation of $d$ Cohen's index, which is used to assess the financial consequences of the company's location in the report.

Table 5. d Cohena (source: own study based on CSO data).
The darker the background in table 5 the stronger the consequences of functioning in the sprawl zone.

\begin{tabular}{l|ccccccccc}
\multicolumn{1}{c|}{ Grup } & $\mathrm{B}_{(\mathrm{w})}$ & $\mathrm{B}_{(\mathrm{pt})}$ & $\mathrm{B}_{(\mathrm{es})}$ & $\mathrm{B}_{(\mathrm{en})}$ & $\mathrm{S}_{(\mathrm{rv})}$ & $\mathrm{A}_{(\mathrm{pi})}$ & $\mathrm{A}_{(\mathrm{ur})}$ & $\mathrm{A}_{(\mathrm{sc})}$ & $\mathrm{A}_{(\mathrm{rr})}$ \\
\hline $\mathrm{AG}_{1}$ & -0.120 & -0.749 & -0.291 & -0.712 & -0.345 & 0.281 & 0.690 & -0.072 & 0.544 \\
$\mathrm{AG}_{2}$ & -0.199 & -0.806 & -0.359 & -0.927 & -0.340 & 0.339 & 0.840 & -0.146 & 0.608
\end{tabular}

The test results presented in tables 4 and 5 should be reflected in three analytical cross-sections: (1) cost analysis, (2) sales revenue analysis, (3) asset resource analysis. With regard to the functioning costs of enterprises located in the sprawl zone, all indicators from $B_{(w)}$ to $B_{(e n)}$ in the study group have lower values than in the case of the control group. This means that the costs that can be related to the space, i.e., property taxes, external services, energy and wages, are lower in the sprawl zone than in the core cities. The $d$ Cohen's 
index for these indicators pays particular attention to $\mathrm{B}_{(\mathrm{pt})}$ and $\mathrm{B}_{(\mathrm{en})}$. The first one indicates that the company's operating costs are taxed with real-estate taxes. For enterprises operating in the $\mathrm{AG}_{1}$ zone, these are much lower tax burdens, and for enterprises in the $\mathrm{AG}_{2}$ zone, these are very significant benefits in terms of operating costs. The same applies to the second indicator reflecting the energy cost load. The benefits for enterprises operating in the sprawl zone resulting from lower energy costs should be assessed as high $\left(\mathrm{AG}_{1}\right)$ or very high $\left(\mathrm{AG}_{2}\right)$. In the case of enterprises operating in the sprawl zone, lower burdens resulting from external services can also be noticed - $\mathrm{B}_{(\mathrm{pt})}$. These benefits should be assessed as moderate. Wages - $\mathrm{B}_{(\mathrm{w})}$ - also burden the operating costs of companies in the sprawl zone to a lower extent. Based on $d$ Cohena's, however, these do not reflect a significantly lower cost burden. In conclusion, it should be assessed that the costs associated with the space are noticeably lower in the sprawl zone than in the core city, representing a financial advantage for companies, which should encourage them to relocate to urban sprawl zone.

Lower space costs can result in lower overall operating costs. In the company, we may also have a cost shift associated with higher other costs that are not analyzed in this study, and that may be the result of being located in the sprawl zone. Hence, the analysis of sales revenues - $\mathrm{S}_{(\mathrm{rv})}$ - is important -and it is based on the cost of sales and thus assesses the profitability of the entity's operation. The lower the value of $\mathrm{S}_{(\mathrm{rv})}$, the more profitable the business is. The performed calculations indicate that $\mathrm{S}_{(\mathrm{rv})}$ in a sprawl zone $\left(\mathrm{AG}_{1}\right.$ and $\mathrm{AG}_{2}$ ) is lower than in the control group. On the other hand, the $d$ Cohena's value fluctuates within -0.34. These results mean that it is more profitable for the economic entities to function in the sprawl zone, and this benefit can be assessed as moderate. Thus, the results of $\left.\mathrm{S}_{\mathrm{(rv}}\right)$ in comparison with the cost analysis allow for the conclusion that the suburban location results in the reduction of spatial costs, without negative consequences for other cost items and sales revenues.

The analysis of property resources in the context of indicators from $\mathrm{A}_{(\mathrm{pi})}$ to $\mathrm{A}_{(\mathrm{rr})}$ extends the assessment of the profitability of the company's operation with those enterprise resources that can be assigned to space. This perspective broadens the assessment of the profitability of the functioning of companies in the smooth zone. The asset productivity ratio $\mathrm{A}_{(\mathrm{pi})}$ in the analyzed groups (6.3 and 6.8) is higher than in the control group (4.0). This means that enterprises operating in the sprawl zone show an advantage of physical assets over financial ones, which puts them in a better position in terms of production possibilities. This difference, in the context of $d$ Cohena's, can be assessed as moderate. A more favorable situation can also be observed in the case of

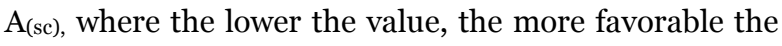
situation of companies. Because in suburban enterprises the value of passive fixed assets (land, buildings, structures) is lower than in cities, the $A_{(\text {(sc) }}$ is therefore lower. Hence, suburban enterprises allocate their financial resources to the expansion of production lines, and not to passive fixed assets that do not contribute directly to the increase in production. Particular attention should be paid to the two remaining indicators, namely $\mathrm{A}_{(\mathrm{ur})}$ use of assets and $\mathrm{A}_{(\mathrm{rr})}$ profitability of assets. Both indicators represent levels that signal financial benefits from the functioning of companies in the sprawl zone. The asset utilization ratio is higher in AG (1.6 and 1.7) than in CG (1.1), which in the light of $d$ Cohena is assessed as a large $\left(\mathrm{AG}_{1}\right)$ or very large $\left(\mathrm{AG}_{2}\right)$ difference. This means that entities benefit from locating in the sprawl zone through much greater ability to generate sales revenues. The assets of these companies are much better used in the production process. Also the asset profitability ratio $\mathrm{A}_{(\mathrm{rr})}$ is higher in AG (0.08 and 0.09) than in CG (0.04), which in the light of $d$ Cohena is assessed as a large difference. These results confirm the benefits of being located in the sprawl zone. According to this indicator, the benefit relates to cost reduction, a more efficient use of fixed capital and a more intensive use of production factors.

Summarizing the results of the research in the presented three analytical cross-sections, the benefits of companies functioning in sprawl zone are noteworthy. All indicators show more favourable values, which confirms the profitability of operating in the sprawl zone. There are no indicators for which the values would cast doubt on the profitability of functioning in the suburban area.

The current state of knowledge regarding the models of decentralization of urban functions indicates that the dispersion of jobs from the centre to the suburbia results from a more favourable economic calculation of enterprises (Alonso, 1964; Fujita and Ogawa, 1982; Heikkila and Wang, 2009). The research presented in the article confirms the global achievements in Polish conditions, as the higher profitability of the functioning of enterprises in the urban sprawl area than in the city centre has been proved.

It should also be noted the achievements of decentralization models, which indicate two main cost benefits associated with the suburban location of enterprises, which are: lower costs of wages and realestate (Li et al., 2019). In the light of the conducted research, these conclusions are also confirmed in the case of Polish urban areas. The added value of the research is explaining the cost mechanism that affects the previously demonstrated profitability of enterprises operating in the urban sprawl zone. Entities located in the urban sprawl zone have lower operating costs, and the burden of these costs with location-sensitive 
expenses is also significantly lower. Studies have shown that lower operating costs are burdensome: wages and salaries, property taxes, energy, including fuels.

\section{CONCLUSION}

The presented research is related to the natural evolution theory, especially the models of decentralization of urban functions (Alonso, 1964; Lave, 1974; Fujita and Ogawa, 1982; Heikkila and Wang, 2009; Li et al., 2019). So far, these concepts have taken up rather simple suburbanization processes. There are no models in the economic literature attempting to explain suburbanization characterized by the spontaneity of spatial development. In the present article, we attempted to fill this gap in the present state of knowledge by examining enterprises located in a spontaneously built-up space.

The current state of knowledge regarding models of decentralization of urban functions indicates that the dispersion of jobs from the center to the suburbs results from a more favourable economic calculation of enterprises (Bayoh et al., 2002; $\mathrm{Wu}$, 2007; Hołuj, 2018). Two main benefits are indicated in these models (Li et al., 2019): lower costs of remuneration and real-estate. In the light of the research carried out in this article, these conclusions can be confirmed in the case of Polish urban areas. The added value of research in the field of lower wage costs is to show that these costs are not significantly lower than in the core city. In turn, the added value in terms of lower real estate costs is the indication that these are very large benefits that relate to: real-estate taxes; energy, foreign services. The indication of the financial mechanism of the benefits of location in the urban sprawl zone is also a contribution to the current literature. Such a location results in the reduction of the company's costs related to space, without negative consequences on other cost items and sales revenues. In the light of the research, suburban enterprises are characterized by the predominance of tangible assets over the financial ones, in terms of production possibilities. These enterprises allocate their financial resources to the expansion of production lines, and not to passive fixed assets that do not contribute directly to the increase in production. Entities located in the sprawl zone benefit from localization through much greater ability to generate sales revenues. The assets of these companies are much better used in the production process. The discussed mechanism relates to the reduction of spatial costs, more efficient use of fixed assets and more intensive use of production factors. As a result of the operation of the described mechanism, higher efficiency of the functioning of enterprises located in the urban sprawl zone was proved. In this case, the mechanism was associated with higher profitability of the use of the property.
The presented research results are of significant importance for the formation of spatial as well as socio-economic policy of metropolitan areas. Apart from the research on the financial consequences for households and the local government sector, they constitute a relevant diagnosis related to the functioning of the economy under urban sprawl conditions. This diagnosis can represent the basis for the formulation of public policy goals and tools for its implementation. From this perspective, urban sprawl does not appear to be a spatial phenomenon that requires restrictive policy goals. Rather, the policy goals concerning urban sprawl should not negatively affect growing suburban businesses.The mechanism of lower operating costs in the suburban area described in this study has a positive effect on the metropolitan economy by higher productivity and efficiency. Hence, it should be noted that maintaining economic growth in a metropolitan area requires local governments of suburban communes to maintain real-estate taxes at a stable and lower level compared to the core city.

Taking into account the research results, the main hypothesis that urban sprawl is beneficial for enterprises is positively verified. The present research results are an extension of the current state of knowledge, although some original concepts may have some limitations. The main limitation is the static measurement of financial consequences. A dynamic analysis would enable a more accurate verification of the hypothesis. This limitation also sets the directions for future research on the financial consequences of urban sprawl.

\section{ACKNOWLEDGEMENTS}

This work was supported by the National Science Centre, Poland under Grant no. UMO2016/23/D/HS4/02961, ("Financial Mechanisms in the Economy Resulting from the Phenomenon of Urban Sprawl”).

\section{REFERENCES}

Alonso W. (1964), Location and Land Use. Harvard University Press. Cambridge. ISBN 9-780-67473-0854.

Bayoh I., Irwin E. G., Haab T. (2002), Flight from Blight vs. Natural Evolution: Determinants of Household Residential Location Choice and Suburbanization. In 2002 Annual meeting. July 28-31. Long Beach. CA (No. 19668). American Agricultural Economics Association (New Name 2008: Agricultural and Applied Economics Association), 2-3. DOI: 10.22004/ag.econ.19668

Brueckner J. K. (1987), The structure of urban equilibria: A unified treatment of the Muth-Mills model. In: Mills E.S. (ed.) Urban Economics. Vol. 2 of Handbook of Regional and Urban Economics,Elsevier, 


\section{Business Urban Sprawl. A Financial Evaluation of Enterprises in Poland Journal of Settlements and Spatial Planning, Special Issue, (2022) 5-13 Cities, Suburbs and Peripheries in Theory and Empirical Research}

821-845. DOI: https://doi.org/10.1016/S1574oo8o(87)80oo6-8

Fujita M., Ogawa H. (1982), Multiple equilibria and structural transition of non-monocentric urban configurations. Regional Science and Urban Economics, 12(2), 161-196. DOI: https://doi.org/10.1016/o1660462(82)90031-X

Fujita M., Thisse J.-F. (2002), Economics of Agglomeration: Cities. Industrial Location. and Regional Growth. Cambridge University Press. New York. ISBN: 978-0521801386

Heikkila E. J., Wang Y. (2009), Fujita and Ogawa revisited: anagent-based modeling approach. Environment and Planning B: Planning and Design, 36(4), 741-756. DOI: https://doi.org/10.1068/b34080

Hołuj A. (2018), Ekonomiczne i ekologiczne efekty zewnętrzne w planowaniu przestrzennym. Folia Oeconomica. Acta Universitatis Lodziensis, 4(336), 137155. DOI: https://doi.org/10.18778/0208-6018.336.09 Lave L. B. (1974), Urban externalities. Papers from the Urban Economics Conference 1973, vol. 1, Centre for Environmental Studies, London, 37-95.

Lityński P., Hołuj A. (2020), Urban Sprawl Risk Delimitation: The Concept for Spatial Planning Policy in Poland. Sustainability, 12(7), 2637, 1-19. DOI: https://doi.org/10.3390/su12072637

Livingston E. H., Elliot A., Hynan L., Cao J. (2009), Effect size estimation: A necessary component of statistical analysis. Archives of Surgery, 144(8), 706712. DOI: 10.1001/archsurg.2009.150

Li H., Wei Y. D., Wu Y. (2019), Urban amenity, human capital and employment distribution in Shanghai. Habitat International 91, 102025. DOI: 10.1016/ j.habitatint.2019.102025

Mieszkowski P., Mills E. S. (1993), The Causes of Metropolitan Suburbanization. Journal of Economic Perspectives, 7(3), 135-147. DOI: 10.1257/jep.7.3.135

Mills E. S. (1967), An Aggregative Model of Resource Allocation in a Metropolitan Area. American Economic Review, $57 \quad$ (2), $197-210 . \quad$ DOI: https://www.jstor.org/stable/1821621
Mills E. S. (2000), A Thematic History of Urban Economic Analysis. Brookings-Wharton Papers on Urban Affairs. Brookings Institution Press, 1-52. DOI: https://www.jstor.org/stable/25067373

Muth R. F. (1969), Cities and housing: the spatial pattern of urban residential land use. University of Chicago Press. Chicago. ISBN: 0226554139 9780226554136

Nechyba T. J., Walsh R. P. (2004), Urban Sprawl. Journal of Economic Perspectives, 18(4), 177-200. DOI: $10.1257 / 0895330042632681$

Spivey C. (2008), The Mills-Muth Model of Urban Spatial Structure: Surviving the test of time? Urban Studies, 45(2), 295-312. DOI: https://doi.org/10.1177/0042098007085964

Sullivan A. M. (1986), A general equilibrium model with agglomerative economies and decentralized employment. Journal of Urban Economics, 20(1), 5574. DOI: https://doi.org/10.1016/00941190(86)90015-X

Wheaton W. C. (2004), Commuting, congestion, and employment dispersal in cities with mixed land use. Journal of Urban Economics, 55(3), 417-438. DOI: https://doi.org/10.1016/j.jue.2003.12.004

White M. J. (1976), Firm suburbanization and urban subcenters. Journal of Urban Economics, 3(4), 323343. DOI: https://doi.org/10.1016/o0941190(76)90033-4

White M. J. (1988), Location choice and commuting behavior in cities with decentralized employment. Journal of Urban Economics, 24(2), 129-152. DOI: https://doi.org/10.1016/o094-1190(88)90035-6

Wieand K. F. (1987), An extension of the monocentric urban spatial equilibrium model to a multicenter setting: The case of the two-center city. Journal of Urban Economics, 21(3), 259-271. DOI: https://doi.org/10.1016/0094-1190(87)90001-5

Wu J. J. (2007), How Does Suburbanization Affect Local Public Finance and Communities. Review of Agricultural Economics, 29(3), 564-571. DOI:10.1111/j.1467-9353.2007.00371.X 